\title{
Global media and time: A conceptual and historical perspective
}

\author{
Christian Morgner, University of Leicester, Lecturer in Culture and Communication \\ cm570@leicester.ac.uk
}

\begin{abstract}
This paper addresses the role of time and meaning-making in the global mediascape. Particular attention will be paid to the role of past and future narratives, connections of messages with a global outreach and time as a topic of communication. The empirical analysis will use a comparative approach to explore these different dimensions by analysing three global media events, such as, the sinking of the Titanic, the assassination US President John F. Kennedy and the Fukushima Daiichi incident. The main findings of the paper will show that time is a constitutional part in the process of meaning-making in global communication.
\end{abstract}

\section{Keywords}

mediascape, time, communication, global, technologies

\section{Time, globalisation and communication technologies}

A number of theories link the emergence of globalisation to the development of new communication technologies such as satellites, fibre cable and mobile phones (Waters, 1995; Sklair, 1999; Faulstich \& Steininger, 2000; Kellner \& Pierce, 2007; Axford, 2013). In this context, Harvey (1991) overviewed transport and communication technologies since the sixteenth century. In those early days, the average maximum speed of horse-drawn coaches and sailing ships was $10 \mathrm{mph}$. By the 1970s, jet passenger aircraft were flying at speeds of 500-700 mph, effectively making the world 50 times smaller. However, there is general consensus that the global age more fully emerged with the development of new communication technologies in the 1970s - notably satellite- and computer-based forms of communication - that render communication time invariant over distance. Coupled with mass television, satellite communication enables people everywhere to access media communications at the same time, variously described as an annihilation or compression of space and time (Harvey, 1991), a distanciation and emptying of time and space (Giddens, 1990; Appadu- rai, 1990) and a temporal acceleration of interlinkages across distant regions (Lash \& Urry, 1994; Castells, 1996). Although influential models of global communication all highlight time (pace, acceleration and change), or even the annihilation of time, no systematic view of the interaction of time, communication and globalisation has been developed beyond the merely technological. These accounts render time irrelevant or neutral rather than exploring it as a constitutive dimension of global communication, which is discussed mainly in social terms. For instance, theories of global media discuss critically the social effects of the global mass dissemination of media products as leading to socio-cultural homogenisation (Tomlinson, 1991) or to the replacement of a socially stable world by global flows and contra-flows that change constantly and quickly over time (Thussu, 2012). A similar line of thought informs discussion of global media events. ${ }^{1}$ An important study by Dayan and Katz (1992) introduces the idea of time as interruption of routines - that is, processes with set durations - replaced by other processes that take on a ritual function. In this way, the social dimension is foregrounded

1 Roche (2003) raises the issue of time, but only in contrast to the everyday experience of time and not media events themselves. 
to engender a sense of community in the face of crisis. Recent overviews by Couldry, Hepp, and Krotz (2010) and Mitu and Poulakidakos (2016), surveying multiple diverse studies of media events in a global age, make no mention of the issue of time.

To address this omission, this article reflects on the correlation between time, meaning-making and the global mediascape by developing a typology of the ways in which various media (e.g. newspapers, television, social networks) configure events as objects of global interest and concern. The main focus here is to characterise the configuration of events as a process of communicative meaning-making in the context of time. (This line of thought is typically associated with pragmatist approaches; see Baert \& da Silva, 2010). In this paper, three important aspects of time will be considered: (1) the constitutive role of the past and future as sense-making strategies; (2) how media messages are interlinked in the present, and how this impacts on communicative meaning-making; and (3) the meta-media discourse around time itself.

\section{Methodology and cases}

Studies of globalisation and communication technologies such as those mentioned above have relied strongly on examples combining mass television with satellite technologies. Recent developments in social media (Facebook or Twitter) are less often considered, and pre-1970s media technologies such as telegraphs, sea-cables, radio and newspapers also tend to be neglected. In exploring a possible typology of global communication in the context of time, it therefore seems relevant to select empirical phenomena that reflect these stages of its evolution. The present study considers three events that broadly represent these different stages: the sinking of the Titanic in 1912, the assassination of John F. Kennedy in 1963 and the Fukushima Incident in 2011.

The Titanic disaster occurred before the advent of radio or television, in an age when global communication depended largely on the printing press and the mass distribution of newspapers. By the time of the assassination of John F. Kennedy new media like television were in widespread use. Finally, as the most recent event to be discussed here, the Fukushima catastrophe occurred in an age dominated by digital communication. Because this article is concerned with the development of a general typology, it is important to cover a variety of different events to explicate basic concepts. Rather than haphazardly comparing a large number of cases, as when using certain quantitative techniques, this study draws on the method of comparison used in Grounded Theory (Glaser \& Strauss, 1967). As the selected events happened in three different global regions (North America, Western Europe and Asia), the contrasting data are well suited to this approach. While the chosen cases all had a significant global impact, duration and are still remembered, they occurred in quite distinct historical settings and disparate media environments. As all of the events were reported to audiences outside the countries in which they occurred, it seemed important here to include a range of cultural regions and their local programme structures. The historical dimension facilitates evaluation of the differing impacts of media technologies in the three cases. This seems critical, as perceptions of large-scale events within a short time are often influenced by the speed and instant communication capability of new media technologies.

In summary, the three cases were selected for their qualities of maximal distance or contrast, as well as some specific shared features that are also characteristic of other social phenomena. The Grounded Theory approach draws on Max Weber's typology of ideal cases, as well as comparative methodologies from functionalism that are now an established aspect of media research (Krotz, 2005).

\subsection{The sinking of the Titanic}

Although the sinking of the passenger steamship RMS Titanic occurred more than 100 years ago, it is still remembered in contemporary society through Hollywood 
movies and other media products. Only a few studies have discussed the sinking from a media events perspective, mainly in the context of how it is remembered (Heyer, 1995; Liebes, 1997). In particular, research to date has tended to focus on the role of cinema and other fictional accounts (McGee, 1999; Cox, 2003; Zani, 2003; Keane, 2006; Brown, McDonagh, \& Shultz, 2013) rather than on global media coverage of the event.

On the night of 14-15 April 1912, the passenger steamship RMS Titanic crashed into an iceberg. The ship's SOS was relayed by other ships and reached a Canadian coast station shortly after the collision, from where it was passed on to New York. During the night, the front pages of North American papers were changed, but the mass media response to the event was still relatively minor. This was due to an error in the news relayed, which suggested that although the Titanic had hit an iceberg, the ship had not sunk but had been towed to Halifax (the nearest harbour), and that all the passengers had been saved. Nonetheless, mass media interest was awakened, and relatives travelled to the shipping company's offices in New York and Southampton seeking more detailed information. This information emerged soon after, prompting widespread reaction. "The world's greatest steamship disaster" was the headline in the 16 April 1912 edition of the USA's Easton Express. In similar vein, the Straits Times of Singapore reported "The most appalling shipping disaster on record”. (“Great Ship Sinks", 1912, p. 7). The German newspaper Frankfurter Zeitung ("Frühere Schiffskatastrophen", 1912, p. 2) called the sinking of the steamship Titanic: "the greatest of all ship accidents ever to occur". The New York Times of 16 April 1912 (“Titanic Sinks", 1912, p. 1) reported that "The Titanic, the biggest steamship of the world, had been sunk by an iceberg." The headline of the British Daily Sketch (as cited in Bryceson 1997, p. 16) ran "Biggest boat in the world collides with an iceberg".

The global reaction and the extraordinary quality, weight and relevance of the event are not determined by the fact of catastrophe alone; the sense of the extraor- dinary derives from a mode of comparison employed as a sense-making strategy. For instance, the evening edition of the Frankfurter Zeitung ("Frühere Schiffskatastrophen”, 1912, p. 2) published a comparison of shipping accidents in the 40 years preceding 1912 to characterise this as the greatest shipping disaster in recent history in terms of loss of human life. ${ }^{2}$ A similar list was published in the Daily Sketch ("The sinking of the Titanic is the greatest disaster that has ever overtaken a liner in point of loss of life", as cited in Bryceson, 1997, p. 26), and in the New York Times ("Many Great Liners Paid Toll of the Sea", 1912, p. 8), which provided an even more detailed list of other marine disasters since the 1850s.

These comparisons were extended to encompass a range of other catastrophic events - for instance, in the New York Times editorial, a comparison was drawn with the San Francisco earthquake of 1906 ("Editorial Note", p. 2 and "Lloyds Staggered by Loss", 1912, p. 1). The past is presented here in quantitative mode; no other event in recent history could be compared to the profound loss and destruction caused by the sinking of the Titanic. However, in a more reflective comparison, the Lisbon Earthquake (see Landauer 1912, p. 1) was discussed in the wider context of sense-making - why do these events occur, and what can be done about them? In this way, the past is presented not simply as a matter of fact but as a point of reference and reflection, against which current events can be contextualised.

This reflective quality is more apparent in media coverage that presents events as a point in time that alters the future development of humankind, and in the discourse about time itself - referring in particular here to the time-independence of communication technologies (in this case, the wireless telegraph). Media coverage addressed the future incidentally

2 In several cases, these comparisons with a global event adopt a regional outlook. For instance, the Sydney Morning Herald ("Loss of the Titanic" 1912, p. 18) reminded its readers of the recent loss of ships from its own country, such as the Waratah and the Yongala. 
and in more factual fashion, discussing for instance how the Titanic disaster would affect regulation and the perceived safety of marine travel. However, more profound readings have a more fictional quality, interpreting the disaster in the context of civilisation itself. According to Elias (2000, p. 6), the term civilised "describes a social quality of people [...] which does not refer directly to people themselves, but exclusively to particular human accomplishments". Representing the highest state of human development, this definition "emphasizes what is common to all human beings" (Elias 2000, p. 7). In some media coverage, the Titanic was presented as one such peak of humanity's technological progress. According to the press, the Titanic was "The world's greatest and most luxurious liner" ("Practically unsinkable", 1912). It was the fastest steamship in the world, with the latest technological equipment (wireless telegraph and automatic self-closing bulkhead doors; see "Eine Äußerung des Generaldirektors Ballin", 1912) and the "Titanic was the last cry and the faultless reach in the science and art of shipbuilding. It was supposed to be irreproachable and incomparable" ("The Titanic Crime", 1912).

This notion of a historic peak is part of a scenario that questions the future progress of civilisation. Here, the notion of progress was seen to be defeated by a failure to take account of the forces of nature (see Heckscher, cited in Köster \& Lischeid, 2000, p. 39). The drive for new records and higher profits may have led to the catastrophe; the press mentions high speed despite the iceberg warning, as well as an insufficient number of rescue boats, which led to many deaths (see "Lack of Lifeboats Believed to Be Cause of the Heavy Loss on the Great White Star Liner", 1912; “The Titanic Crime”, 1912; "Der Untergang der 'Titanic'”, 1912). In other words, society's drive towards progress has caused its own downfall, and in this sense, the catastrophe has a contingent quality, as it might have been prevented if society were not driven by these norms.

This contingent quality was another important narrative informing media cov- erage of these events, taking the form of a discourse on reversed time and the instantaneity of the wireless telegraph, and how this technology might have relayed news of the accident just in time. Reversed time, referring to a fictional discourse that imagines how a catastrophe might be reversed, is in fact central to the Ancient Greek concept of catastrophe, which meant an overturning of something. In the case of the Titanic's sinking, the Manchester Guardian suggested that "A continuous wireless service should be made compulsory on every ship" ("Lessons of the Disaster: How to Guard against its Repetition", 1912, p. 10), as this may have prevented the tragedy. According to the New York Times, "Wireless Instruments on the Seas Should Be Available Continually" ("Wireless only on 50 Ships", 1912, p. 3). These and other reports shared the view that this technology "uses the air waves in the service of communication" (Landauer 1912, p. 1); that its "speeding messages" made an "almost magic use of the air" ("Wireless Crowns a Remarkable Record as Life-Saver”, 1912, p. SM2); or reported "the benefit of wireless as being so instantaneous" (Wireless and the Titanic, 1912, p. 8). This discourse on time and on the instantaneous quality of wireless emphasises how it might have prevented the disasters altogether - that is, how it might have reversed time. ${ }^{3}$

These references to wireless telegraphy and submarine cables in newspapers that appeared several times daily prompted a communication dynamic in which the mass media simulated reactions to the catastrophe as a global interaction (Kern, 1983). This is exemplified in various nations' messages of condolence and sympathy, notably the British and German reactions as reported in the German press and the responses in Singapore's Straits Times and Australia's Sydney Morning Herald. The German Reichstag opened at 2.30 p.m. on April 16, 1912 with a memorial speech by President of the Chamber Kämpf ("Beileidsbekundungen im

3 The story of the courageous wireless operator who served until his death is not only reported, but receives widespread illustration in newspapers around the globe. 
Reichstag - Abendblatt", 1912; "Beileidsbekundungen im Reichstag - Erstes Morgenblatt”, 1912). Kämpf expressed his pain at the loss of many relatives and friends from other countries, explicitly emphasising the British people's loss while also mentioning his own nation's loss. Just two days later, the speech was also reported in Australia's Sydney Morning Herald ("In the Reichstag”, 1912, p. 9). A similar event in the British House of Commons on April 16,1912 was also picked up by the German press ("Beileidsbekundungen im englischen Unterhaus”, 1912).

These reports were then thematised as reactions to the event became news in itself. The Straits Times reported that the German Reichstag stood up as a sign of sympathy as the President expressed his condolences to Great Britain and other nations (Untitled, The Straits Times, 1912), and the House of Commons session was also commented upon ("Prime Minister's Statement", 1912). On 18 April, the Straits Times further reported that the British monarch and Queen Alexandra, the German Kaiser and Prince Henry of Prussia had all expressed their sympathy and condolences ("Titanic Disaster", 1912), and that "The Kaiser has telegraphed to King George his sympathy, and other expressions of world-wide sympathy have been received" (“The Kaiser's Sympathy”, 1912). And despite the great distance between Germany and Singapore, the same report was to be found in the Frankfurter Zeitung of the same day.

Among many other such reactions, which became increasingly reciprocal, an excerpt from the German Kaiser's telegram was printed in the Frankfurter Zeitung, followed by excerpts from British reactions (“Der Untergang der Titanic", 1912). On 19 April, as well as reporting on the donations sent by many nations, the Straits Times referred to the sympathy and condolences expressed by King George and the British Queen and by President Taft of the United States ("Titanic Disaster", 1912). Taft's response was printed alongside an item entitled "The American people share the sorrow of kinsmen oversea's" ("Memorial Service in London", 1912, p. 9). The same chain of responses was covered in the Australian Press; the Sydney Morning Herald reported on the message of King George and the reply from President Taft under the headline "Community of Grief" (1912). In turn, Sir Edward Grey of the British Foreign Office offered his thanks for the many expressions of condolences from across the globe ("Memorial Service in London", 1912). On 19 April, the German press reported on the British reaction to the German Reichstag's reaction and President Kämpf's speech, in which the British government expressed its thanks and simultaneously offered its condolences for the loss of German passengers ("Deutscher Reichstag", 1912). These reactions to the reactions then became the subject of mass media reports, creating circular interlinkages, as in 'News of the 'Titanic's' distress and cry for help was heard throughout the world almost simultaneously" (Landauer, 1912, p. 1) or the Sydney Morning Herald's "World-wide Sympathy" (1912).

This brief overview of international press coverage of the Titanic sinking captures the interaction of time, communication and meaning-making in three different dimensions. The past provided a context in which to assess and evaluate the event, to contrast it with other events, and to establish its exceptional nature. The future informed a narrative of reflection and criticism and linked the sinking to a broader discussion of human progress and safety. In this context, there emerged in particular a discourse on time, with particular reference to the role of wireless telegraphy. Here, the emphasis was on the contingent nature of the event and how it might have been prevented if the seemingly instant technology of the wireless telegraph had been standard. Finally, the overview illustrates how media reporting of the event was interlinked with other media messages across the globe, creating density and inner meaning.

\subsection{The assassination of John F. Kennedy}

Like the Titanic, John F. Kennedy remains an icon in popular culture and media folklore (see DeLloyd \& Wrone, 1980; Frewin, 1993; Edges, 2003), and a number of pub- 
lished studies have explored media coverage of his assassination in 1963. In the first of these, Baker (1965) focused solely on American newspapers, excluding television or any global coverage of the event. Ralston (1996) was more international in scope but examined the reactions in the world of sport rather than in the mass media. While most of the research on this subject is historical in focus and addresses political descriptions of the assassination rather than media coverage (Ralston 1999), some studies discuss the role of collective memory and journalism (Zelizer, 1992), filmic accounts of the assassination (Simon, 1996) and the impact of television coverage on image practices in contemporary society (Lubin, 2003). In their research on media events, Dayan and Katz (1992) used the assassination as a key example, but they focused solely on the burial and did not consider TV coverage from other countries.

On 22 November 1963, at 11:30 a.m. local time (Central Standard Time), Air Force One landed at Love Airfield in Dallas, Texas. Following a reception at the airport, President John F. Kennedy, Governor John Connally of Texas and their wives climbed into an open limousine and set off in convoy through downtown Dallas. At 12:30 CST, several shots rang out, and at 12:32, the local radio station WFAA reported that Kennedy had been shot. ABC Radio's Don Gardiner reported three shots fired at 12:36, and at the same time (12:36), NBC television was already discussing the events with Robert McNeil. About five minutes after the shooting, the first report by Merriman Smith went out on UPI's wire service. The three major television networks then interrupted their programming - CBS at 12:43, ABC at 12:48 and NBC at 12:53 - to provide continuous live coverage of events as they unfolded.

In Germany, half an hour after the shooting at 20:00 local time (Central European Time), TV broadcasting was interrupted by a news programme reporting on the events in Dallas (Die Tagesschau, 22 November 1963, 20:00, archive number
2844). ${ }^{4}$ By this time (some 30 minutes after the shooting), $68 \%$ of the U.S. population had been informed of the event (Sheatsley \& Feldman, 1965, p. 152). At 13:27 CST, CBS anchor Walter Cronkite announced that President Kennedy had died, with official confirmation following at 13:35. At approximately 20:30 CET, ARD (German television) broadcast the report and abandoned its regular schedule for the day. At 14:13 CST, UPI wires reported that a suspect had been arrested in a cinema; within the next hour, he was named as Lee Harvey Oswald. During this same time frame, news was broadcast of the swearing-in of Vice President Lyndon B. Johnson as the new president. Within less than two hours of the shooting, the message had reached $92 \%$ of the U.S. population (Sheatsley \& Feldman, 1965, p. 152). The BBC and other European radio and television channels in Ireland, France, Italy and elsewhere echoed the German news reaction, and the report was broadcast on Moscow television's evening news at 10:00 p.m. (Brigham, 1963). Radio and television stations in other Eastern European countries, such as Hungary and the former Yugoslavia, also interrupted their programming.

Because of the time difference, the news reached Asia during the night. Japan was one of the first countries in the region to receive the news at 4:00 a.m. local time. Many Japanese rose early to follow the first ever live trans-Pacific broadcast from the United States. Before the broadcast, Shinzo Koike, Minister of Posts and Telecommunications, announced that Kennedy had been the victim of an assassination attempt ("Slaying cancels US-Japan talks", The New York Times, 1963, p. 12). Even in the Antarctic, at the outer limits of civilisation, the news reached the U.S. Marine Base at McMurdo Sound within 90 minutes and was retransmitted 20 minutes later to the outstation at the South Pole (cf. "Memorial Service at Antarctic Base", The Malay Mail, 1963, p. 2).

Media coverage of the event, then, was on a global scale and almost simultaneous,

4 The reel number and timeline refer to archival holdings of the German news coverage of the event, as in the ARD archive in Hamburg. 
leading to an interlinking of reactions that in turn informed the media event itself. By way of illustration, the present analysis will examine media coverage of Soviet media reaction in other countries around the world. This analysis will focus more on the temporal aspect of these connections than on the subject matter (re. the latter, see Dunning, 1964).

One of the first reports covered by the Soviet news agency TASS related to speculation about reasons for the assassination, as already broadcast on NBC at $3.30 \mathrm{pm}$ EST on 22 November 1963. According to NBC, news of the assassination was of interest beyond the Soviet media and was relayed immediately to political elites in Moscow. The event interrupted scheduled programmes on soviet broadcaster, and this interruption itself became a news item and was reported by NBC. At around 5:45 p.m. EST (Reel 7-22.11.1963 24:35), ${ }^{5}$ NBC broadcast statements from a number of Soviet politicians and other important figures. The Minister for Foreign Affairs, Andrei Gromyko, was quoted as expressing his shock and condolences, and NBC further reported that the general public in the Soviet Union had been informed of events. At around 6:00 p.m., NBC reported this report, adding that these reactions from the Soviet Union reflected reactions around the globe.

One of the first messages broadcast by NBC the following morning (at around 7:00 a.m. EST) stated that President Johnson had received a message from President Khrushchev (Reel 20-23.11.1963 03:13), who described the loss of John F. Kennedy as a loss to world peace and cooperation between the two countries. NBC further reported that Khrushchev wore a black suit when he went to the American Embassy to sign a message of condolence. The TV station emphasised that this act was unusual for the Soviet statesman (Reel 20-23.11.1963 03:51). That report was followed shortly after by pictures of

5 The reel number and timeline refer to archival holdings of the NBC news coverage of the event, as in the JFK Library in Boston. The time refers to the time as on the respective reel. this episode (Reel 24-23.11.1963 20:05), adding that Khrushchev had declared his intention to send Gromyko to the funeral. The extraordinary quality of these acts was highlighted in the media in presenting the two men as fierce opponents on a global level, pointing to the assassination's future consequences: "Two men held the world in their hands, now one is dead [...] his passing will affect all spheres of life not only in your country, but throughout the globe" (Reel 25-23.11.1963 14:15). This future dimension was linked to the new U.S. President Lyndon B. Johnson, and media reported further exchanges between the two world leaders. NBC also reported that Soviet television broadcast footage of the funeral, as well as reports about Soviet radio and newspaper messages, over the following three days.

The German 8pm news programme Die Tagesschau (Reel No. 2845) also showed footage of Khrushchev and his signature of condolence. The filmic account was accompanied by a report that Khrushchev had described Kennedy's death as a shock for all for those who believe in world peace and for cooperation between the U.S. and the Soviet Union. That broadcast also stated that Khrushchev had interrupted his scheduled visit to the Ukraine, and that he had sent a direct telegram to Lyndon B. Johnson. The reports included the front page of the newspaper Pravda, which remained open to re-edit the newspaper. On the day of the funeral (25 November 1963), a German news programme (Reel No 2847) reported that a mass organised in Moscow was attended by more than 500 diplomats, and that also Nina Khrushchev had signed the book of condolences at the U.S. Embassy.

In the Federation of Malaya, TV coverage was more limited, as Radio-Television Malaya was still in its early days. The few existing reports mainly show people gathering in front of the U.S. Embassy and reading newspapers about the event. While newspapers were still the main media channel, they also cited other media - for instance, the front page of the Sunday Times from 24 November 1963 quotes the Soviet agency TASS but also refers to 
television and radio programmes in Moscow that interrupted their broadcasts. The newspaper shows a still from the footage of Khrushchev visiting the U.S. Embassy and cites his message of condolence ("Black Suit, Nikita Signs Book", 1963). The Sunday Times noted that the assassination had captured the full attention of media in the Soviet Union and reported a wish to continue with existing policies ("Johnson to Continue Kennedy's Policies”, 1963). The events in Moscow were increasingly presented as a narrative linking to events in the U.S. The Straits Times (26 November 1963 , p. 6) printed a picture of Khrushchev visiting the Embassy, and its report underlined this notion: "Deadline Dallas [...] it began with a shock on Friday, Nov. 22: The shock registers on a famous face in far-away Moscow". Khrushchev's shocked reaction is described as being unable to grasp such an event, leading the newspaper to conclude that "In retrospect President Kennedy's murder may be seen as the first world event to draw together the communist and the non-communist worlds".

The interruption of scheduled programmes and of visits became in itself a message. In other words, the temporal interruption of some planned or expected event becomes the narrative that links messages from various regions into a common flow. In the present context, the role of television is foregrounded as central to the discourse around time, in the interruption of global communication by media communication itself. This interruption serves as a separating element, as something that was happening and would have continued ends and is replaced by another process. Global media, then, experiences a double interruption, not only reporting the event as an interruption but interrupting its own program to do so: “... television's most powerful gesture consists precisely in interrupting the continuous flow of its programs..." (Dayan \& Katz, 1998, p. 162). In this way, media discourse applies the discrepancy/normalcy schema to itself in presenting its own processing of the non-processed as significant.

The historic evolution of the mass media as separate social sphere goes hand in hand with regular, periodic appearance detached from whether something can actually be described as extraordinary or different (Groth, 1928). For mass media, time is autonomous, and has at its disposal the regularity of mass communication itself. Whatever society or mass media may see as a source of news, newspapers retain the same format and appear every day, just like television programmes. This standardisation and continuity have had a significant impact on the temporality of mass media. During media events, this continuity can be applied to mass media itself by replacing one with another as a "special report" or "breaking news". The conspicuousness of the conspicuous has a kind of twofold relevance that can be exponentially extended; one can report not only on the fact that the regular programme has been interrupted but also on the behaviour of other channels: "After reporting the death of Kennedy, Italian TV and radio went off for silent music" (NBC Reel 2 \& 3-22/11/1963 47:34). This also applies to newspapers: "The State radio and the Irish television station cancelled all previously scheduled programs" ("Memories of visit add to Irish grief”, 1963, p. 5). A broadcast from the Soviet Union declared: "Comrades, radio-listeners, we have interrupted our broadcast because of the sorrowful report which has just been received from New York" ("World shocked", 1963, p. 1).

Among global media, television has a special kind of access here. The newspaper industry can print special pages or redesign front pages, but it remains in newspaper mode. Television, however, can engender a double (or even a triple) interruption. One does not simply report (as in the case of the newspaper) on the event as interruption - that is, as something that brings life to a standstill. (At the time of the Kennedy assassination, there were numerous reports of cancelled sporting events, closed cinemas, even the closure of Disney Park.) Dayan and Katz (1994) referred to the "high holidays" of the mass media; in this case, the media emphasised the interruption caused by this interruption almost every hour over four days. The reflections of the event were then reflected upon so 
many times that the event gained in size and scope.

The other relevant temporal aspect here is the role of the past in global media. ${ }^{6}$ Kennedy's death was compared to the deaths of Theodore Roosevelt, Abraham Lincoln, the Archduke Franz Ferdinand of Austria or Gandhi of India, or to Pearl Harbor or the dropping of the atomic bomb on Hiroshima. Comparisons of this kind locate Kennedy's assassination in the context of other well-known events. In the New York Times of 23 November 1963, a lengthy article compared assassination attempts on U.S. Presidents and other well-known personalities. To this end, it drew primarily on images, ${ }^{7}$ showing six in total: a lithograph depicting Lincoln's death; an illustration of Garfield's death from Frank Leslie's Illustrated Newspapers; a painting by T. Dart Walker of McKinley's assassination; a photograph of the assassination attempt on Roosevelt; and a picture of the wounded assassin (lying on a stretcher) who attempted to kill Harry S. Truman. There was also a picture of Kennedy, taken during his final ride through Dallas, accompanied by the following caption: "Moments before assassination ... shortly after this picture was taken, rifle fire hit the President and the Governor". This pictorial material recalled other assassination attempts and focused on the moment of the assassination. Repetition of a pictorial theme enhanced the effect while establishing a mutually stabilised relevance: "a well-known photograph [...] then becomes even better known. There is a certain power of redundancy" (Goldberg, 1991, p. 219). In this sense, one can speak of climactic images, which serve to make a particular moment visible while testifying to and reinforcing its relevance (Mersch, 2006).

6 The future was an important temporal category in this event, but mainly raised used as to speculate about future consequences, in particular, with regard to nuclear disbarment and cooperation between the US and Soviet Union.

7 There were similar reports in other media, see the Frankfurter Allgemeine Zeitung of 25 November 1963, p. 5.
The concept of memory employed in this media discourse is that of comparison. Like Pearl Harbor or the assassination of the heir to the Austrian throne, these comparisons were regionally limited, establishing links with other parts of the world through regional comparison. In a global context, however, the comparison is between John F. Kennedy and Abraham Lincoln. The first obvious similarity is that both men were President of the United States, and both were assassinated - an unheard-of event since the death of Abraham Lincoln, according to Die Tagesschau (23 November 1963, 20:00, archive number 2845). But that does not particularly set this event apart from the case of the Titanic; using event as criterion of comparison signals a similarity - or even, to an extent, a formal relationship between the cases. However, this case also entails a contrast, which can be described in terms of values. On ARD (German television), President Gerstenmaier of the German parliament quoted Lincoln and elevated both Kennedy and Johnson as representatives of a tradition with a great impact on the lives of others. ${ }^{8}$ The Straits Times quoted a similar example; Kennedy was called "the second emancipator" by Afro-American celebrities, and Lincoln was known as "the great emancipator" ("President's last moments", 1963, p. 2). Again, Lincoln was described as the instigator of the civil rights movement and Kennedy as "the modern Abraham Lincoln". 9 Globally, then, the mass media linked Lincoln and Kennedy using the criterion of "values". Here, the semantics of "values" works at what Luhmann calls "inviolate levels" (2012, p. 298), in the sense that they are unconditional points of

8 Eulogy of Bundestag President Dr. Gerstenmaier on the death of President Kennedy, 22 November 1963, Video Tape: Sammelträger A 3144-04 WDR,

9 The president of the Asian Regional Organization (part of the ICFTUf) PP Narayanan described Kennedy as 'the modern Abraham Lincoln'. A similar message from Senator PLC Nathan (the National Union of Plantation Workers - NUPW) was distributed to more than two thousand Malaysian plantation workers (Tengku orders all flags to be flown at half mast, 1963, p. 5). 
reference without contingencies, forming a self-referential semantics that needs no further explanation. Referring to Kennedy as the guardian of freedom, humanity and world peace is seen to be a global reference, understood by all humanity. Despite the contingency and uniqueness of the event and the related paradoxical situation of not being able to fully account for it, the mass media made a values-based comparison with Lincoln as an uncontestable point of reference. Kennedy's death represents an aberration, standing above everything, and in this sense, it is a world event.

This analysis demonstrates how the global circulation and interlinking of messages was made possible, in particular, through television. The possibility of interrupting a scheduled programme to replace media messages by other media messages is an important narrative that links messages to other messages from around the globe. TV coverage in the Soviet Union and the accompanying interruption itself becomes a news item that is broadcast in the U.S., Germany and Malaysia. The discourse about time and the linking of media messages to media messages in the present become intertwined. Finally, the event was compared to other events and especially to the assassination of Abraham Lincoln. While media coverage of the Titanic made comparisons in terms of loss of life, this comparative mode was much more value-driven in the case of Kennedy, adverting to a transcendental order that would lift this event into the realm of the extraordinary.

\subsection{The Fukushima catastrophe}

What has become known as the Fukushima catastrophe or 3.11 refers to a triple disaster in Japan - earthquake, tsunami, and nuclear meltdown - on 11 March 2011. The meltdown in several reactors of the Fukushima Daiichi Nuclear Power Plant occurred when the plant was hit by a tsunami wave triggered by an undersea earthquake off the Pacific coast of Tōhoku. More than 15,000 people died and over 300,000 were evacuated. The estimated economic cost was several hundred billion Euros.
Numerous studies have examined media coverage of this event (see Katchanovski, 2012; Ylönen et al., 2015; Gomez, Roses, \& Rivera, 2014; Park, Wang, \& Pinto, 2016; Kristiansen, Bonfadelli, \& Kovic, 2016; Ionescu, 2012; Perko, Turcanu, \& Gennen, 2012; Schmidt et al., 2012; Lazic \& Kaigo, 2013). However, most of these studies focused on individual countries and mainly traditional media, especially newspapers; recent evidence suggests that the mediascape informing this event has changed somewhat, and that the role of social media should be taken into account (Friedman, 2011; Digital Archive of Japan's 2011 Disasters, 2011; Independent Investigation \& Bricker 2014). As an example, Twitter $^{10}$ experienced a $500 \%$ increase in tweets from Japan. The volume of tweets spiked to more than 5,000 tweets per second on several occasions following the tsunami and ensuing nuclear accident, and in the first days of the disaster, a total of 177 million tweets were sent, representing an increase of almost a third in tweets at that time (Chowdhury, 2011; Twitter, 2011).

Social media, then, complemented or augmented traditional media and other new media platforms. For instance, when teachers Naoko Utsumi and Koharu Hayashi had to evacuate kindergarten students with disabilities, they did not have time to flee further inland and evacuated the children to the roof of the school. Ms. Utsumi emailed what might have been her final words to her son, Naohito, from a mobile phone. As Naohito was 10,000 miles away in London, he tweeted the message and asked anyone who saw it to help. Back in Tokyo, Shuichi Suzuki retweeted the message, addressing it to the Vice Governor of Tokyo. The latter alerted the Disaster Defence Director of Tokyo's Fire Department, which is based in a nearby office, and they organised a helicopter to rescue everyone safely (see "Rescued from a sea of fire (with a Tweet)", 2011).

10 It should be noted that Twitter has been very popular in Japan, since its Japanese-language introduction in 2008. Tweeting in Japan had become so popular that Japanese is the second most used language after English (Seshagiri 2014). 
Global media coverage of the event made reference to a range of other media events. Chernobyl and Three Mile Island were referenced in Western media, and these were also mentioned in Japanese media, along with events closer to home such as the Great Kantõ earthquake of 1923 and the Great Hanshin earthquake of 1995. World War II was also mentioned; Prime Minister Naoto Kan's assertion that Japan faced its biggest crisis since the war was reprinted in a range of media (see Branigan, 2011; "Worst crisis since WWII - Japan PM”, 2011; Thielke, 2011; “Japan Earthquake 2011”, 2011; “Japan PM”, 2011; "Japan facing worst crisis since World War II: Naoto", 2011). Across the different media, this event was contextualised by comparison with the destruction of World War II, but additionally, 3.11 was framed as a challenge, posing the open question of whether and how it might be overcome. In other words, the past was presented as future past - not just looking back, but as a reference for possible impacts, possible developments and unforeseen consequences.

Accounts of a contingent future or future realities were prevalent across all media, as in these Twitter posts: "Electric companies know well enough that earthquakes could cause the worst to happen to a nuclear power plant” (@saltfish_nsk 2011, emphasis by the author, cited in Preston, 2011); and "If people didn't waste electricity, there wouldn't be a need for these facilities and things like this wouldn't have had to happen... We should seriously tackle the issue of electricity waste" (@ mokko0307 2011, emphasis by the author, cited in Preston, 2011). This theme was also reflected in the major headlines of the day; "Japan Reels as Tool Rises and Nuclear Risks Loom" (New York Times, 2011, emphasis by the author); "Tokyo Warns of Possibility of another Reactor Hit with a Blast" (The Sun [Malaysia], 2011, emphasis by the author) and "Angst vor atomarer Katastrophe/Fear of Nuclear Disaster" (Frankfurter Allgemeine Zeitung, 2011, emphasis by the author). All of these stressed the contingency of what might happen, or what could have happened, or should not have happened. Typical of the keywords informing these narratives are chaos or hell; iconic images stressed destruction, chaos and disorientation, as in the picture of a girl (Yuko Sugimoto) wrapped in a blanket and standing in front of a pile of debris. She is alone in the middle of chaos, with no visible help or other people; the world is turned upside-down, signifying the contingency of future impacts as central to the narrative. This notion of contingency effectively mandated a re-evaluation of all previous communication, as established frames of interpretation imploded in the face of such destruction. Contingency means that the future present could be this or that, calling into question how the past and the present are organised and hindering extrapolation of a possible future. As a consequence, the future has to be discussed.

The other strand of the narrative aimed at what might be characterised as control, in which established frames, procedures and guidelines suffice to deal with the event. This narrative was employed when referring to management of the crisis and technical descriptions, as well as to reassure the wider public about the safety of nuclear energy and its role in society (Perko, Turcanu, \& Gennen, 2012). In principle, both narratives can be seen to have a global dimension, but it was the element of contingency that linked communications around the globe - not as a homogenous theme but by reformulating the universal message of a contingent future according to local circumstances. For instance, in Germany, which has a strong tradition of green thinking, there was a strong local reaction to the event. Discussion there centred on the role of nuclear energy in society and led to the conservative government's decision to end Germany's nuclear programme. In contrast, discussion in Japan focused on the ideology of technological control and how Japanese culture's avoidance of criticism might have played a different role (Martin, 2011; for examples from France, see de la Poype \& Sood, 2012). In short, the unifying symbolism of a contingent future informed a global narrative that linked different locales. 
This universal particularism - and, in particular, the question of future impact - was central in configuring the image of a shared community as global horizon. Shared community encompassed two aspects: 1) shared, meaning a common base of knowledge and understanding and 2) community, referring to a socio-spatial arrangement of all people as part of a single society. Any impact on one group in this community would be seen as a crisis for the whole community, not least because it would be understood to be transmissible in time to all others. For instance, the devastating effects of losing friends and relatives and the ensuing feelings of loss, anger and angst are symbols to which anyone can relate. In a guide for users in Japan, Twitter stated: "At Twitter, we feel that it is part of our duty to do whatever we can, no matter how little, to support those during times of need like this" (Addison, 2011).

As mentioned above, this sharing of a future or horizon requires authentication at local level. Alexander (2003) showed how this demands episodes of repeated cultural, authentic and local communication for consolidation of the social metaphors that are crucial for a shared understanding of complex events. Social media such as Twitter, Google's People Finder, Mixi, Facebook and blogs perform such a role (Hickins, 2011; Friedman, 2011). As a good example of this (Murthy, 2013; Neal, 2013), Twitter combines online social networking and a microblogging service. Its users can send and receive short (140-character) messages known as tweets, and the service can be accessed through web interfaces, SMS or mobile device apps. Two important features of Twitter are the retweet and hashtag functions. A retweet is a tweet from someone else that can be selected and shared with everyone in one's own network. Hashtags allow specific topics to be created under which these retweets can be summoned. In the case of 3.11, the most common hashtags were \#fukushima, \#japanquake and \#prayforjapan. The first tweet was sent one minute and 25 seconds after the earthquake (even before CNN began to report on the disaster), and the first tsunami tweet came six minutes after the earthquake (Murthy, 2013). What matters here is not just the pace of message distribution but how these linked up with other messages as retweets.

The visualisation of statistical data (Chowdhury, 2011) representing the number and location of tweets from Japan to the rest of the world and from the rest of the world to Japan immediately after the earthquake demonstrates the global dissemination of the event via social media (see Image 1). However, through Twitter's structure of tweets and retweets, messages were not only sent from Japan to the rest of the world but circulated back to Japan and opened up new circulations and flows across the world (see Image 2).

The structure so created constituted a form of global dialogical exchange. Discussions were not only based on tweets but often relied on traditional media reports, creating another link to television and newspapers reporting social media reactions (Utz, Schultz, \& Glocka, 2013). Although social media may lack overall credibility, the reliability of messages is assured by a chain of trusted people that includes someone directly involved in the event (Thompson \& Ito, 2012). This instant global dialogue enabled participants to engage in discussion about the meaning of the event. That meaning and its future implications are not assessed by the individual but by a community of actors who verify or update the subject. In such circumstances, it is likely that contingency can be better expressed, paying more attention both to doubts and to interpretation (Binder, 2012; Li, Vishwanath, \& Rao, 2014). It is exactly this potential for many people to voice their concerns that lends relevance to the event, enabling feelings of community and togetherness to be built as each individual shares in mourning a loss in a distant region:

Despite residing in L.A., I began to feel that I might be able to contribute to helping people through my personal use of social media. I myself began harnessing social media to participate in circulating the data the DIY movement collected. This experience made 
me realize that I should use my research to do something for people who are suffering from not knowing the risks of unknown exposure to nuclear radiation in Japan. (Abe, n.d.)
Based on a network of traditional and media systems, the linking of messages through the narrative of a contingent future enabled the formation of a global

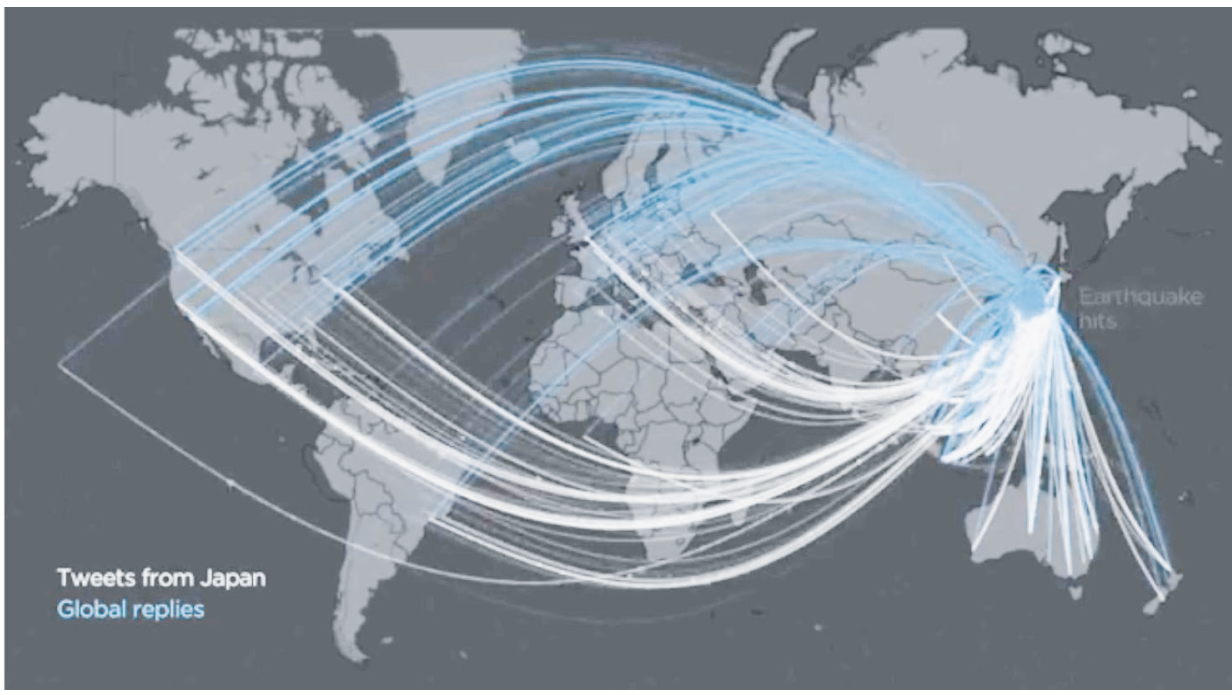

Image 1: Global circulation of tweets. White lines indicate tweets from Japan; blue lines are replies. (Source: Twitter, "Twitter Stories: the world connects during the Tōhoku earthquake" https:// www.youtube.com/watch?v=SybWjN9pKQk)

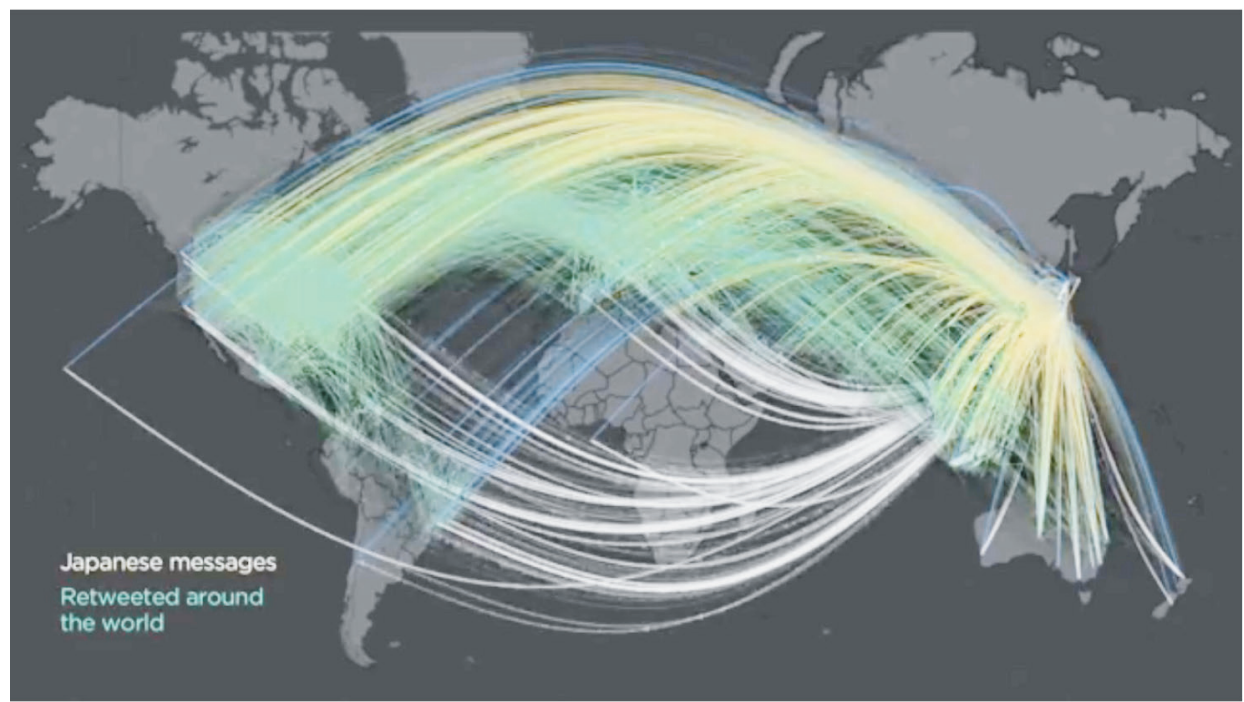

Image 2: Global circulation of tweets. White lines indicate tweets from Japan; blue lines are replies; green and yellow lines represent retweeted messages. (Source: Twitter, "Twitter Stories: the world connects during the Tōhoku earthquake" https://www.youtube.com/watch?v=SybWjN9p$\mathrm{KOk})$ 
horizon, as messages could be related to various local contexts and so incorporate a global audience. In combination with new media and social media, the notion of time and, in particular, the contingency of future developments created a horizon, bringing a global audience under the same umbrella.

\section{Summary: the role of time in the global mediascape}

Many of the authors mentioned earlier have linked globalisation to the development of new communication technologies. Since the 1970s, satellite- and computer-based communication have created a global world. However, the present analysis of media coverage of the Kennedy assassination and especially of the sinking of the Titanic demonstrates that the global circulation and interlinking of messages was already possible at the beginning of the twentieth century. New technologies had not simply triggered interest in these events but were embedded in organisational and institutional procedures (news reporting, printing cycles) and social settings (those who could afford and read newspapers). The temporal structures and media communication of the sinking of the Titanic show how the (re-)printing cycles of daily newspapers, wireless telegraphy and undersea cables, along with media practices employing time as a narrative device (surprise, shock, comparison), enable meaning-making that can encompass the globe. In this context, the overview also demonstrates how the narrative linking messages to other messages can take different forms, influenced by historical shifts in what news analysis refers to as elite nations (see Galtung \& Ruge, 1965). For instance, while the global network of messages during the Titanic episode encompassed reactions in Britain and Germany, media coverage following the assassination of Kennedy focused on the United States and the Soviet Union, and the Fukushima catastrophe shows more diversified interlinking.
In all of this, time is not merely a support structure in the form of a technology that disseminates information and therefore a neutral agent. Rather, time plays a constitutive role in the process of meaning-making in the global mediascape. As frameworks, semantics and schemes of time and remembering are employed by the media to lend meaning to their communications, within a structure that compares the relevance of various media messages. The value-laden nature of these historical contrasts serves to instal this relevance at different levels of society, creating meaning that positions events at a global level. While the past seems to be used to designate meaning, the future serves as a horizon of possibility, reflection and negotiation of meaning, in a contingent future that may or may not come to pass. Here, time is not simply a chronological dimension of media communication or programming but assumes the role of a symbolic structure that can create meaning by questioning the world and engaging in dialogue. The contingent future is not just depending on individual decisions, but the future present itself is to be decided upon. The contingency of this phenomenon is based on a media infrastructure, where this contingency can be reflected upon.

Current approaches to media events theorise this phenomenon as ritual or ceremony (see Dayan \& Katz, 1992); what integrates the different acts and messages is their effect on society at its core, inducing a tacit, underlying, normative consensus that lends meaning to the whole event. This paper contends that while values play an important role in making sense of such global events, they are much more a function of a media recollection of past events. However, the present analysis suggests another theoretical approach. The simultaneous connectivity of global communication seems not to rest on this hidden normative ground but on a structure within global media communication not unlike what conversation analysis characterises as "turn taking", where one participant refers to and anticipates what the other participant will say, as both participants react 
almost simultaneously. This structure is characteristic of the circular, compact nature of news broadcasts, lending an inner density to what has happened and shaping it into an event (Button, 1984).

Mass media coverage of the cases discussed here - the sinking of the Titanic, the assassination of John F. Kennedy and 3.11 - took on a worldwide dimension in referencing other media reports, linking messages through a kind of intertextuality. Following Mead (1967), a theory of media event communication can be formulated as a three-part social process for the constitution of meaning, in which an initial gesture, comment or item of news is accompanied by a reaction and subsequent consequential behaviour. Beyond one's personal reaction, the reactions of others appear different and may prompt further connections. Consequently, one reflects on the reactions of others in light of one's own reaction(s), and vice versa. This requires two things: a follow-up response must be possible, and the respective responses must be perceptible. In terms of time, this means that the news should not be out of date or subsumed into a broader or different context, and any subsequent reaction must remain identifiable as a follow-up communication. This means that participants must remain consistently in the loop if they are to make these connections without losing time, catching up with the news as it happens. It follows that the meaning-making of global media communication may be better described as a form of network-like arrangement, where meaning unfolds and other meanings are interwoven to give the event an internal consistency, scale and dynamic (see Morgner, 2009).

Finally, the typology proposed to account for the role of time has three fundamental dimensions: 1 ) the role of past and future, 2) metacommunication about time and 3) the connection of actual messages to other existing messages. This typology proved useful in comparing different media from different stages of the global mediascape. First, the typology revealed common features across all the selected events, such as the interlinking of messages, cita- tion and intertextual meaning-making, from the sinking of the Titanic in the age of newspapers to the Fukushima incident in the age of tweets and retweets. In this sense, there is a surprising consistency in how these global structures unfold. Second, the typology also revealed variations within these dimensions. It seems that the process of meaning-making is not uniform but can be differentially informed by certain conceptions of time. While the contingent future predominated during the Fukushima incident, the role of memory seems to have exerted a greater influence on meaning-making in media coverage of the assassination of John F. Kennedy, and reporting of the Titanic was shaped by meta-communication about time, especially with regard to wireless telegraphy. Taken together, these findings clearly illustrate that time is crucial to meaning-making in global media communication.

\section{References}

Abe, Y. (n.d.). Analyzing the Fukushima Nuclear Crisis through Uses of Social Media: A Short Essay on a Work in Progress. An STS Forum on Fukushima. Retrieved from http://fukushimaforum.wordpress.com/ online-forum-2/online-forum/fukushima-social-media/

Addison, A. (2011). Digital ways to donate to Japan disaster relief. Retrieved from http:// phys.org/news/2011-03-digital-ways-donate-japan-disaster.html

America stunned: Hollywood stars wept when news of tragedy came. (1963, November 24). The Sunday Mail, p. 18.

Appadurai, A. (1990). Disjuncture and difference in the global economy. Political Culture, 2(3), 1-24.

Augstein, R. (1963). Der Präsident der Stärke und des Friedens. Der Spiegel, 48, 22-29.

Axford, B. (2013). Theories of Globalization. Malden, MA: Polity Press.

Baert, P. \& Carreira da Silva, F. (2010). Social Theory in the Twentieth Century and Beyond (2nd ed.). Cambridge: Polity Press.

Baker, D. C. (1965). The Assassination of President Kennedy: A Study of the Press Cover- 
age. Department of Journalism, University of Michigan, Ann Arbor, Michigan.

Beileidsbekundungen im englischen Unterhaus. (1912, April 17). Frankfurter Zeitung (Zweites Morgenblatt), p. 1.

Beileidsbekundungen im Reichstag. (1912, April 16). Frankfurter Zeitung, Abendblatt, p. 2.

Beileidsbekundungen im Reichstag. (1912, April 17). Frankfurter Zeitung (Erstes Morgenblatt), p. 2.

Benckiser, N. (1963, November 25). Die Welt ohne Kennedy. Frankfurter Allgemeine Zeitung, p. 1.

Binder, A. R. (2012). Figuring Out \#Fukushima: An Initial Look at Functions and Content of US Twitter Commentary About Nuclear Risk. Environmental Communication, 6(2), 268-277.

Black Suit, Nikita Signs Book. (1963, November 24). The Sunday Times, p. 1.

Branigan, T. (2011, March 13). Earthquake and tsunami 'Japan's worst crisis since second world war.' The Guardian. Retrieved from https://www.theguardian.com/ world $/ 2011 / \mathrm{mar} / 13 /$ japan-crisis-worstsince-second-world-war

Brigham, R. (1963, December 6). Warsaw, No, No, This Cannot be True. Life, (55)23, 129-130.

Brown, S., McDonagh, P., \& Shultz, C. J. (2013). Titanic: Consuming the myths and meanings of an ambiguous brand. Journal of Consumer Research, 40(4), 595-614.

Bryceson, D. (1997). The Titanic disaster: As reported in the British national press, AprilJuly 1912. London: W. W. Norton.

Button, G. \& Casey, N. (1984). Generating topic: the use of topic initial elicitors. In M. J. Atkinson \& J. Heritage (Eds.), Structures of Social Action: Studies in Conversation Analysis (pp. 167-190). Cambridge: Cambridge University Press.

Castells, M. (1996). The Rise of the Network Society. Oxford: Blackwell.

Chowdhury, A. (2011, June 29). Global pulse. [Twitter Blog Post]. Retrieved from https:// blog.twitter.com/2011/global-pulse

Community of Grief. (1912, April 19). The Sydney Morning Herald, p. 9.

Couldry, N., Hepp, A., \& Krotz, F. (Eds.). (2010). Media Events in a Global Age. Abingdon: Routledge.
Cox, S. (2003). The Titanic and the art of myth. Critical Review, 15(3), 403-434.

Dayan, D. \& Katz, E. (1992). Media Events: the Live Broadcasting of History. Cambridge: Harvard University Press.

Dayan, D. \& Katz, E. (1994). Defining Media Events: High Holidays of Mass Communication. In H. Newcomb (Ed.), Television. The Critical View (5th ed.) (pp.332-351). New York, Oxford: Oxford University Press.

Dayan, D. \& Katz, E. (1998). Articulating consensus: the ritual and rhetoric of media events. In C. J. Alexander (Ed.), Durkheimian Sociology: Cultural Studies (pp.161186). Cambridge: Cambridge University Press.

De La Poype, A. L. \& Sood, S. (2012). Public Sphere Dialogue in Online Newspapers and Social Spaces: The Nuclear Debate in Post Fukushima France. Public Communication Review, 2(2), 30-47.

DeLloyd, G. J. \& Wrone, D. R. (1980). The Assassination of John F. Kennedy: A Comprehensive Historical and Legal Bibliography, 1963-1979. Westport, London: Greenwood Press.

Der Untergang der Titanic. (1912, April 17). Frankfurter Zeitung (Erstes Morgenblatt), p. 1.

Der Untergang der Titanic. (1912, April 18). Frankfurter Zeitung (Erstes Morgenblatt), p. 2.

Deutscher Reichstag. (1912, April 19). Frankfurter Zeitung (Erstes Morgenblatt), p. 2.

Die amerikanische Nation nimmt im Capitol Abschied/Beisetzung am Dienstag auf dem Nationalfriedhof in Arlington/erste Proklamation des neuen Präsidenten Johnson. (1963, November 25). Frankfurter Allgemeine Zeitung, p. 1.

Digital Archive of Japan's 2011 Disasters. (2011). Reichschauer Reports, 16(1), 6-7.

Dunning, J. L. (1964). The Kennedy Assassination as Viewed by Communist Media. Journalism Quarterly, 41(2), 163-169.

Edges, A. (2003). John F. Kennedy. München: Deutscher Taschenbuch Verlag.

Editorial. (1912, April 19). The New York Times, p. 2.

Eine Äußerung des Generaldirektors Ballin. (1912, 17 April). Frankfurter Zeitung (Zweites Morgenblatt), p. 1. 
Elias, N. (2000). The Civilizing Process (2nd ed.). Oxford: Wiley-Blackwell.

Emerson, B. M. \& Perse, E. M. (1995). Media events and sports orientations to the 1992 Winter Olympics. Journal of International Communication, 2(1), 80-99.

Faulstich, W. \& Steininger, C. (Eds.). (2000). Zeit in den Medien-Medien in der Zeit. München: Wilhelm Fink Verlag.

Frewin, A. (1993). The Assassination of John F. Kennedy: An Annotated Film, TV and Videography, 1963-1992. Westport, London: Greenwood Press.

Friedman, S. M. (2011). Three Mile Island, Chernobyl, and Fukushima: An analysis of traditional and new media coverage of nuclear accidents and radiation. Bulletin of the Atomic Scientists, 67(5), 55-65.

Frühere Schiffskatastrophen. (1912, April 16). Frankfurter Zeitung (Abendblatt), p. 2.

Galtung, J. \& Ruge, M. H. (1965). The Structure of Foreign News. The Presentation of the Congo, Cuba and Cyprus Crises in Four Norwegian Newspapers. Journal of Peace Research, 2, 64-91.

Giddens, A. (1990). The Consequences of Modernity. Stanford: Stanford University Press.

Glaser, B. G. \& Strauss, A. L. (1967). The Discovery of Grounded Theory. Strategies for Qualitative Research. Chicago: Aldine Pub. Co.

Goldberg, V. (1991). The Power of Photography: How Photographs Changed Our Lives. New York, London, Paris: Abbeville Press.

Gómez, C., Roses, S., \& Rivera, A. (2014). Fukushima nuclear power plant accident. An analysis of the most relevant frames in the Spanish press. Communication \& Society/Comunicación y Sociedad, 27(3), 65-81.

Groth, O. (1928). Die Zeitung. Ein System der Zeitungskunde (Journalistik), Volume 1. Mannheim, Berlin, Leipzig: J. Bensheimer. Groys, B. (2002). On the New. Retrieved from http://www.uoc.edu/artnodes/espai/eng/ art/groys1002/groys1002.html

Harvey, D. (1991). The Condition of Postmodernity: An Enquiry into the Origins of Cultural Change. Oxford: Wiley-Blackwell.

Heckscher, F. (1912, April 23). Untergang der 'Titanic' und öffentliche Meinung. In Hamburger Fremdenblatt, Abendzeitung, cited in W. Köster \& T. Lischeid (Eds.),
Titanic. Ein Medienmythos (pp. 39-43). Leipzig: Reclam Verlag, 2000.

Heyer. P. (1995). Titanic Legacy: Disaster as Media Event and Myth. Westport, CT: Praeger Publishers.

Hickins, M. (2011, March 14). Facebook Supporting Japan Quake Communication [Wall Street Journal. [Blog post]. Retrieved from http://blogs.wsj.com/digits/2011/03/14/facebook-supporting-japan-quake-communication/

Hodgson, G. (1963, November 27). What the new man faces .... The Straits Times, p. 10.

In the Reichstag (1912, April 18). The Sydney Morning Herald, p. 9.

Independent Investigation Committee on the Fukushima Nuclear Accident. (edited by Mindy Kay Bricker). (2014). The Fukushima Daiichi Nuclear Power Station Disaster. London: Routledge.

Ionescu, T. B. (2012). Communicating in Germany about the Fukushima Accident: How Direct Encounter Beat Media Representations. Environmental Communication, 6(2): 260-267.

Japan Earthquake 2011: 'Most Severe Crisis' Since World War II, Prime Minister Says. (2011, March 13). The Huffington Post. Retrieved from http://www.huffingtonpost. com/2011/03/13/japan-earthquake-mostsevere-crisis-world-war-ii_n_835021.html

Japan facing worst crisis since World War II: Naoto. (2011, March 13). Pakistan Today. Retrieved from http://www.pakistantoday. com.pk/2011/03/13/foreign/japan-facingworst-crisis-since-world-war-ii-naoto/

Japan PM: Nation facing worst crisis since World War II. (2011, March 13). Haaretz. Retrieved from http://www.haaretz.com/ news/world/japan-pm-nation-facingworst-crisis-since-world-war-ii-1.348894

Jeffrey, A. C. (2003). The Meanings of Social Life: A Cultural Sociology. New York: Oxford University Press.

Johnson calls on world to mourn. (1963, November 25). The Straits Times, p. 1.

Johnson to Continue Kennedy's Policies. (1963, November 25). The Straits Times, p. 3.

Katchanovski, I. (2012). Fukushima vs. Chernobyl: Coverage of the Nuclear Disasters by American and Canadian Media. In APSA 2012 Annual Meeting Paper. 
Keane, S. (2006). Disaster movies: The cinema of catastrophe. New York: Wallflower Press.

Kellner, D. \& Pierce, C. (2007). Media and Globalization. In G. Ritzer (Ed.), The Blackwell Companion to Globalization (pp. 383-395). Oxford: Wiley-Blackwell.

Kern, S. (1983). The culture of time and space: 1880-1918. London: Weidenfeld \& Nicolson.

Koselleck, R. (1985). Futures Past: On the Semantics of Historical Time. Cambridge, MA: MIT Press.

Kristiansen, S., Bonfadelli, H., \& Kovic, M. (2016). Risk Perception of Nuclear Energy After Fukushima: Stability and Change in Public Opinion in Switzerland. International Journal of Public Opinion Research, doi:10.1093/ijpor/edw021.

Krotz, F. (2005). Neue Theorien Entwickeln. Köln: Herbert von Halem Verlag.

Lack of Lifeboats Believed to Be Cause of the Heavy Loss on the Great White Star Liner. (1912, April 16). New York American, p. 5.

Landauer, G. (1912, April 21). Die Botschaft der 'Titanic.' Frankfurter Zeitung (Erstes Morgenblatt), p. 1.

Lash, S. \& Urry, J. (1994). Economies of Signs and Space. London: TCS/Sage.

Lazic, D. (2013). News Analysis of the Fukushima Accident: Lack of Information Disclosure, Radiation Fears and Accountability Issues. Journal of Contemporary Eastern Asia, 12(2), 19-34.

Lazic, D. \& Kaigo, M. (2013). US press coverage of the Fukushima nuclear power plant accident: Frames, sources and news domestication. Media Asia, 40(3), 260-273.

Lessons of the Disaster: How to Guard against its Repetition. (1912, April 23). Manchester Guardian, p. 10.

Li, J., Vishwanath, A., \& Rao, H. R. (2014). Retweeting the Fukushima nuclear radiation disaster. Communications of the ACM, $57(1), 78-85$.

Liebes, T. (1997). Review of Titanic Legacy: Disaster as Media Event and Myth (Paul Heyer). Journal of Communication, 47(2): 62-165.

Lincoln plotters thwarted in 1861. Ghandi and Trotsky slain - 1914 killing touched off the First World War. (1963, November 23). The New York Times, p. 10.
Lloyds Staggered by Loss. By Marconi Transatlantic Wireless Telegraph to The New York Times. (1912, April 18). The New York Times, p. 1.

Loss of the Titanic. (1912, April 17). The Sydney Morning Herald, p. 18.

Lubin, D. M. (2003). Shooting Kennedy: JFK and the Culture of Images. Berkeley: University of California Press.

Luhmann, N. (2012). Theory of Society, Vol. 1. Stanford: Stanford University Press.

Many great liners paid toll of the sea. (1912, April 16). The New York Times, p. 8

Many nations share America's grief. Asia - Karachi: 'Dastardly Act.' (1963, November 24). The New York Times, p. 6.

Martin, R. (2011). When Japan Sneezes, Germany Catches a Cold. The European. Retrieved from http://www.theeuropean-magazine.com/257-martin-ralph/258-fukushimas-media-coverage

McGee, P. (1999). Terrible Beauties: Messianic Time and the Image of Social Redemption in James Cameron's Titanic. Postmodern Culture, 10(1). doi: 10.1353/pmc.1999.0034

Mead, G. H. (1967). Mind, Self, \& Society: from the Standpoint of a Social Behaviorist. Chicago, London: University of Chicago Press.

Mein Gott, wohin geraten wir. (1963, November 25). Frankfurter Allgemeine Zeitung, p. 3.

Memorial Service at Antarctic Base. (1963, November 25). The Malay Mail, p. 2.

Memorial Service in London. (1912, April 20). The Straits Times, p. 9.

Memories of visit add to Irish grief. (1963, November 23). The New York Times, p. 5.

Mersch, D. (2006). Der versteinerte Augenblick. Zum Verhältnis von Kunst und Ereignis zwischen Barock und Moderne. Retrieved from www.momo-berlin.de/mersch_augenblick.html

Mikoyan is going to capital rites. Premier sends messages and calls on Kohler - TV newscasts are shown. (1963, November 24). The New York Times, p. 6.

Mitu, B. \& Poulakidakos, S. (Eds.). (2016). Media Events: A Critical Contemporary Approach. Basingstoke: Palgrave Macmillan.

Morgner, C. (2009). Weltmedienereignisse als Netzwerke. Soziale Systeme, 15(2), 317-344. 
Murder on TV: This was what viewers saw at home. (1963, November 26). The Straits Times, p. 1.

Neal, R. W. (2013, November 18). Twitter Usage Statistics: Which Country Has the Most Active Twitter Population? International Business. Retrieved from http:// www.ibtimes.com/twitter-usage-statistics-which-country-has-most-active-twitter-population-1474852

No title. (1963, November 26). The Straits Times, p. 6.

Park, D. J., Wang, W., \& Pinto, J. (2016). Beyond Disaster and Risk: Post-Fukushima Nuclear News in U.S. and German Press. Communication, Culture \& Critique, 9 , 417-437.

People across US voice grief and revulsion. (1963, November 23). The New York Times, p. 11.

Perko, T., Turcanu, C., \& Gennen, D. (2012). Media reporting and changes in public opinion after Fukushima nuclear accident: Belgium as case study. International Journal of Nuclear Governance, Economy and Ecology, 3(4), 291-307.

Practically unsinkable. (17 April, 1912). The Straits Times, p. 7.

President's last moments. (1963, November 24). The Straits Times, p. 2.

Preston, J. (2011, March 13). After Quake and Tsunami, Japanese Citizens Flock to Social Networks for Information. [Blog Post]. Media Decoder. Retrieved from http://mediadecoder.blogs.nytimes.com/2011/03/13/ after-quake-and-tsunami-japanese-citizens-flock-to-social-networks-for-information /?_php=true\&_type=blogs\&_ $\mathrm{php}=$ true \&_type $=$ blogs \&_r $=1$

Prime Minister's Statement. (1912, April 17). The Straits Times, p. 7.

Ralston, F. R. (1999). The Media and the Kennedy Assassination: The Social Construction of Reality (Dissertation). Iowa State University, Iowa.

Rescued from a sea of fire (with a Tweet). (2011). Twitter Stories. Retrieved from https://stories.twitter.com/en/japan_rescue.html

Reston, J. (1963, November 24). Cabinet convenes. Johnson sees Truman and Eisenhower on first day in office. The New York Times, p. 1.
Roche, M. (2003). Mega-events, Time and Modernity: On Time Structures in Global Society. Time \& Society, 12, 99-126.

Roche, M. (2006). Part 1 sports mega-events, modernity and capitalist economies: mega-events and modernity revisited: globalization and the case of the Olympics. The Sociological Review, 54, 25-40.

Rocking chair is back. (1963, November 28). The Straits Times, p. 13.

Rowe, D. \& Stevenson, D. (2005). Sydney 2000: Sociality and Spatiality in Global Media Events. In A. Tomlinson and C. Young (Eds.), National Identity and Global Sports Events: Culture, Politics, and Spectacle in the Olympics and the Football World Cup (pp. 197-214). Albany, NY: State University of New York Press.

S.S. Titanic: Great Ship Sinks in Atlantic. (1912, April 17). The Straits Times, p. 7.

Schmidt, L, Horta, A., Pereira S., \& Oliveira C. (2012). Portuguese media discourse on nuclear energy before and after Fukushima. Working Paper 12SERACIF1, prepared for the EFDA Workshop programme.

Scott, C. E. (1999). The Time of Memory. Albany, NY: State University of New York Press.

Seshagiri, A. (2014, March 4). The Languages of Twitter Users. The New York Times. Retrieved from http://bits.blogs.nytimes. com/2014/03/09/the-languages-of-twitter-users/?_php=true\&_type=blogs\&_r=1

Sheatsley, P. B. \& Feldman, J. J. (1965). A National Survey on Public Reactions and Behaviour. In B. S. Greenberg \& E. B. Parker (Eds.), The Kennedy Assassination and the American Public: Social Communication in Crisis (pp. 149-177). Stanford, CA: Stanford University Press.

Simon, A. (1996). Dangerous Knowledge: The JFK Assassination in Art and Film. Philadelphia: Temple University Press.

Sklair, L. (1999). Competing Conceptions of Globalization. Journal of World-Systems Research, 5(2), 142-163.

Slaying cancels US-Japan talks. (1963, November 23). The New York Times, p. 12.

Solemn Khrushchev Mourns 'a Realistic Politician'. (1963, November 26). The Straits Times, p. 2.

Strike in Palermo postponed. (1963, November 24). The New York Times, p. 13. 
Tengku orders all flags to be flown at half mast. Jack gave US 'best chance to meet the red challenge' - Untimely death. (1963, November 24). The Straits Times, p. 5.

The Kaiser's Sympathy. (1912, April 18). The Straits Times, p. 9.

The Titanic Crime. (1912, April 16). Evening Journal, p. 1.

The world's greatest steamship disaster. (1912, April 16). Easton Express, p.1.

Thielke, T. (2011, March 13). Japan Battling 'Worst Crisis Since World War II'. Der Spiegel. Retrieved from http://www.spiegel.de/ international/world/aftermath-of-deadlyquake-japan-battling-worst-crisis-sinceworld-war-ii-a-750682.html

Thomson, R. \& Ito, N. (2012). Social Responsibility and Sharing Behaviors Online: The Twitter-sphere's Response to the Fukushima Disaster. International Journal of Cyber Society and Education, 5(1), 55-74.

Thussu, D. (2012). Mapping Global Media Flow and Contra-Flow. In: F. Lechner \& J. Boli (Eds.), The Globalization Reader (pp. 352357). Oxford: Wiley-Blackwell.

Titanic Disaster. (1912, April 18). The Straits Times, p. 9

Titanic sinks four hours after hitting iceberg. (1912, April 16). The New York Times, p. 1

Tomlinson, J. (1991). Cultural Imperialism: A Critical Introduction. Baltimore: Johns Hopkins University Press.

Truce in Toledo news strike. (1963, November 23). The New York Times, p. 11.

Twitter (2011, March 4) \#numbers. Retrieved from https://blog.twitter.com/2011/numbers

Untitled. (1912, April 17). The Straits Times, p. 7.

Utz, S., Schultz, F., \& Glocka, S. (2013). Crisis communication online: How medium, crisis type and emotions affected public reactions in the Fukushima Daiichi nuclear disaster. Public Relations Review, 39(1), $40-46$.

Waters, M. (1995). Globalization. London: Routledge.

Wireless and the Titanic. (1912, April 25). The Sydney Morning Herald, p. 8.

Wireless Crowns a Remarkable Record as Life-Saver. (1912, April 21). The New York Times, p. SM2.

Wireless only on 50 Ships. (1912, April 23). The New York Times, p. 3.
World shocked by this 'most terrible attack'. (1963, November 23). The Malay Mail, p. 1. World-wide Sympathy. (1912, April 20). The Sydney Morning Herald, p. 17.

Worst crisis since WWII - Japan PM. (2011, March 14). The Sydney Morning Herald. Retrieved from http://www.smh.com.au/ environment/worst-crisis-since-wwii--japan-pm-20110313-1btje.html

Ylönen, M., Litmanen, T., Kojo M., \& Lindell, P. (2015). The (de)politicisation of nuclear power: The Finnish discussion after Fukushima. Public Understanding of Science. doi: 10.1177/0963662515613678

Zani, S. J. (2003). Traumatic Disaster and Titanic Recuperation: Popular/Historical Representations of the Titanic. Journal of Popular Film and Television, 31(3): 125-131.

Zelizer, B. (1992). Covering the Body: The Kennedy Assassination, the Media, and the Shaping of Collective Memory. Chicago, London: The University of Chicago Press. 